the first six or seven days it preferred to stand on its heels, and usually rose to its toes, that is, the normal position of the adult, only when walking.

The bird often ate indigestible things, little stones, \&c., not, as it appeared to me, altogether accidentally, but chiefly and purposely, after it had made a good meal off some living food-Tenebrio larvæ, Limnæus, or the like. Smaller edible things like ants' chrysalids it picked off the ground itself very early, but larger morsels, bits of fish, mice, \&c., it only takes when held in the hand and presented to it even now, when it is eight weeks old. The stones, \&c., it occasionally eats, and the hair and larger bones it has swallowed it brings up and vomits in a mass. It lost the thorn of the beak on the fourth day and began to fly a little after four weeks ; when seven weeks old it began to make longer excursions, and flewwithout precept or example-very well. It has, however, not yet attained to anything like the elegant flight of full-grown gulls, and occasionally makes an involuntary somersault in the air when trying to soar or rest on the wind without flapping its wings.

Prague.

R. v, LENDENFELD.

\section{The Effect of Light on Cyanin.}

WHILE working on the reflective power of cyanin mirrors I have noticed some very interesting effects of light on that substance. Freshly fused cyanin is of a deep metallic bronze colour, but exposure to light turns it plum colour and finally a steely blue-black. In the moderate light of a cloudy day the change is perceptible in half an hour, in direct sunlight in less than a minute. The complete change to blue-black requires an exposure of about twenty hours to diffuse daylight or half an hour to direct sunlight. It has long been known that cyanin is un. suitable for use as a cloth dye on account of its rapid fading in sunlight, but recent investigators of the optical properties of this substance appear to have overlooked this light effect. That the effect is purely photographic and not due to any rise in temperature is shown by the fact that long-continued heating in the dark produces no trace of discoloration. On the contrary, the effect of heating is to reverse the effect produced by the light, for a thin coating of cyanin, exposed until blue-black throughout, returns nearly to its original bronze colour on fusion or longcontinued heating in the dark. By an exposure of thirty hours I have obtained on cyanin easily recognisable photographs of small, well-illuminated objects. A cyanin mirror, or better yet a piece of ground glass washed over with fused cyanin, exposed for ten hours to the spectrum of a Nernst lamp shows the effect to be very strong in the yellow, just perceptible in the adjacent red and green, and imperceptible in the blue and ultra-violet. It appears to correspond with the absorptive index as determined by Pfiiger in various parts of the spectrum. At the same time, the exposure to light greatly decreases the absorbing power where it was originally large, as may be easily seen on looking at a sodium flame or a spectrum through an exposed coating of cyanin. It is as though the absorption were due to molecular resonance and the light produced a fatigue or destruction of this resonating power.

A most noteworthy change in the refractive index accompanies this change in the absorptive index, and is shown by the alteration in the reflecting power. The reflecting power of fresh cyanin is roughly 20 per cent. in the yellow, 2 per cent. in the blue-green and 6.5 per cent, in the ultra-violet. After exposure to light the reflecting power is nearly constant, 6.5 per cent., from the red out to $250 \mu \mu$ in the ultra-violet. Now in the blue-green the absorptive index is so small as not to affect the reflecting power sensibly, so that the refractive index varies from about $I$ 'I to $I \cdot 6$. Evidently work on the optical constants of cyanin is of little value unless carried on without exposure of the cyanin to daylight. A decrease in the absorptive index from 0.75 to nearly zero is indicated by the decrease in the reflecting power in the middle of the yellow, where exposure to light does not. greatly affect the refractive index. The general effect of exposure to light is, then, to remove the absorption band and to destroy the characteristic anomalous dispersion.

The cyanin used was furnished by Kahlbaum, in Berlin, and is the ordinary diamyl iodide, $\mathrm{C}_{29} \mathrm{H}_{33} \mathrm{~N}_{2} \mathrm{I}$, easily soluble in alcohol and ether, but only very slightly soluble in water.

Göttingen, August. P. G. NutTing.

\section{Fog Bow at Oxford.}

A somewhat curious phenomenon, presumably an effect caused by the searchlights at Spithead, was visible here in Oxford on the night of Saturday last.

About II.15 p.m., the night being fine and warm and the sky somewhat overcast, my attention was arrested by the appearance of an arc of whitish light, about $15^{\circ}$ above the south horizon, within which the sky appeared of an intense black. The arc rapidly increased in elevation until, in six or seven minutes' time, it had reached the zenith, forming an arch extending, apparently, to the horizon on the east and west; it then declined northwards, and in another four or five minutes had vanished.

In appearance it suggested a brilliant lunar fog bow, but the light was of a more bluish tint, the interior circumference being far brighter than the outer; the brilliancy did not diminish to any great extent until the bow attained its highest altitude, after which it rapidly become fainter. The distance from Spithead is rather more than seventy miles.

Rawlinson Road, Oxford, August 20.

J. Rose.

\section{Simple Means of Producing Diffraction Effects.}

IN the interesting article on "Photography of Diffraction and Polarisation" published in the issue of NATURE for August 7 , the writer describes various means of producing diffraction effects. It may possibly interest some readers of NATURE to know that beautiful fringes may be seen with even simpler ap. paratus than that described in the article referred to. All that is required is an ordinary folding foot-rule, preferably of ivory. To see diffraction bands by its means, it is only necessary to close the two halves of the rule until they are almost in contact and then to fold them over. On looking at the sun or other bright source of light through both slits, a series of brilliant diffraction bands will be seen.

Tynemouth, August 20.'

\section{Time-Signals by Wireless Telegraphy.}

MAY I suggest that the wireless telegraph offers a means of enabling Greenwich or other astronomical time being sent to ships at sea for the correction of their chronometers and the finding of their longitude? Distinct signals have already been transmitted from England to America, and these are all that is necessary for communicating time. At certain hours of the day or night, for example I p.m., a series of wireless signals, perhaps ten or twenty, at intervals of one second, might be sent from Greenwich far and wide as an extension of the time-ball signal which now serves for ships in the Thames and the Downs. By international regulation these time-signals could be protected from other wireless signals. I need scarcely add that such timesignals would also be useful inland.

JOHN MUNRO.

Croydon, August 25.

\section{THE BELFAST MEETING OF THE BRITISH} ASSOCIATION.

SINCE the publication of our last article on the approaching meeting, the following additional arrangements have been made :-

The local executive committee (chairman, Sir Otto Jaffe) invites members, associates and holders of ladies' tickets to a garden party in Botanic Gardens Park, near Queen's College, on September 15, at 3 to 5.30 p.m.

In connection with this reception, the new fernery recently arranged by Mr. Charles McKim, curator of the Botanic Gardens, will be opened for the first time, and will be found well worth seeing by those interested in ferns and tropical plants.

On September 16, Lord O'Neill gives a garden party at Shane's Castle, picturesquely situated on the shore of Lough Neagh.

The Belfast Harbour Commissioners invite members, associates and holders of ladies' tickets to a reception in the Harbour Office on September I6, at 8 p.m. 
Mr. and Mrs. John Brown will give a garden party at Longhurst on September I I (by invitation). Their guests will be invited by Mr. G. Herbert Brown, J.P., to inspect St. Ellen damask and linen weaving works close by.

Mr. W. S. Bruce, of the Scottish Antarctic Expedition, has arranged that the exploring ship Scotia, recently fitted out, shall, before her departure, visit the harbour during the meeting for inspection by those attending it. The ship is elaborately supplied with instruments and apparatus for zoological, oceanographical and other branches of research, which will be in charge of her scientific staff. The inspection of the ship and her outfit will no doubt form a most interesting incident of the meeting.

Under the able management of Prof. Symington, good progress has been made with the loan exhibition, the following contributions to which will be found of special interest :-

From Mr. W. J. Knowles, a collection of specimens illustrating the various stages in the manufacture of stone implements collected from the remains of an ancient flint implement factory at Cushendal.

From Mr. R. Welch, a collection of Irish jaunting cars illustrating the development of that vehicle from a primitive form ; also series of photographs illustrative of Irish ethnology, local geology and of the more special trade processes of the north of Ireland.

Irish ethnographical collections will also be exhibited by Dr. Scharff, Mr. S. F. Milligan, Mr. W. H. Patterson and Miss E. Davis.

The skeleton of the Irish giant is being kindly sent for exhibition from Trinity College, Dublin.

In connection with Section K (Botany), an interesting collection of Australian plants will be exhibited by Mr. Thomas Steel, as the representative of the Linnean Society of New South Wales.

Mr. R. Lloyd Praeger will exhibit a number of rare Irish plants.

The collection of apparatus employed by the

late Prof. Andrews in his researches on the continuity of the liquid and gaseous states and on beats of combination, \&c., is being carefully arranged by his daughter, Miss Mary Andrews.

Much private hospitality has been offered, but the large number of distinguished members who have signified their intention to attend has thrown considerable strain on the committee having charge of this department.

A forecast of the papers to be brought before most of the sections has already been given (August 7, p. 344; August I 4, p. 377; and August 2I, p. 397). We have now received the following list of papers arranged for the Section of Chemistry:-The president of the Section, Prof. E. Divers, F.R.S., is expected to take the atomic theory as the subject of his address at Belfast. A paper will be read by Dr. G. T. Morgan "On our Present Knowledge of Aromatic Diazo-compounds," and Dr. A. W. Crossley will give a paper "On Reduced Benzene Derivatives containing a Single Nucleus." The following papers, amongst others, will also be read:- "Present Synthetical Research on the Glucosides" and "The Synthetical Action of
Enzymes," by Dr. E. F. Armstrong ; "The Alkylation of the Sugars," by Prof. T. Purdie, F.R.S., and Dr. Irvine ; "The Colour of Iodine containing Compounds," by Miss Ida Smedley; "On Zirconium Hydrate and other Colloids from Elements of the Fourth Group," by Dr. J. H. Gladstone, F.R.S., and Mr. W. Hibbert ; "On some Optical Properties of Tellurium" by Dr. J. H. Gladstone, F.R.S. ; "On the Telluric Distribution of the Elements in Relation to their Atomic Weights," by Mr. W. Ackroyd; "On the Undesirability of Establishing Standard Analytical Methods," by Mr. B. Blount ; "On the Corrosion of Copper by Sea Water and on the Detection of Traces of Impurity in the Commercial Metal," by Dr. E. A. Letts; "On Experiments to Ascertain the Amount of Carbonic Anhydride from Sea Water by Air," by Dr. E. A. Letts and Mr. W. Caldwell : "On the Absorption of Ammonia from Water by Algæ," by Dr. E. A. Letts and Mr. J. S. Jotton; "On the Action of Distilled Water on Lead," by Dr. F. Clowes ; "On the Decomposition of Urea," by Dr. C. E. Fawsitt

The following description by Mr. R. Welch of the new path along the face of the Goban's Cliffs will be of interest to visitors. 
"Seven Sisters" caves it will be carried by a suspension bridge of novel design, 200 feet long. At another place is a swing bridge, suggested by the famous rope bridge of Carrick-a-Rede; here it is no "rock in the road" of the salmon, but a deep gully into a wide cave, "in the road" of the climber. From the path, seals have been seen almost every day in early August ; on one day porpoises were rolling about close inshore, and otters are known to have haunted the place from time immemorial. Some of the fish bones found in digging out a cave which was hidden by a great slip of basalt about forty years ago may be due to otters. Others of birds and mammals certainly are not, but have the appearance of the broken bones so plentiful in the prehistoric middens of Antrim and Down. These were found under from 400 to 500 tons of boulders, partly consolidated with earthy matrix, taken out of the cave, and are now in the hands of the Cave Fauna Committee investigating the Irish cave-deposits. The northern end of the path may not be completed this season, heavy gales having much delayed the work, and the tunnel which it will be necessary to excavate in hard rock at a place where the cliff overhangs very much will take some months to complete.

The first part of the path, that along the picturesque undercliff south of the cliffs section, was completed last year; there the Upper Chalk may be seen in large masses, broken up and slipping over the soft underlying Lias Clay, some sections of which are exposed, with, in a tew places, good sections of Chloritic Chalk, Yellow Sands and Marls, and Glauconitic Sands. Details of these sections with lists of their fossil fauna will be found in Dr. Hume's classical paper on the Cretaceous strata of co. Antrim (Q.J. Geol. Soc., November, I897, pp. 557-560, pl. xliv. and xlv.). The Basalts, I am afraid, have not received the attention here which they deserve, but now that these inaccessible cliffs, tier upon tier of thin lava flows weathering in the most varied manner, can by this new path be easily reached from the land, it is to be hoped they will be visited by many geologists in the near future. The Memoir of the Geological Survey, Ireland, No. 29, gives a brief description of them, with section at south termination. One may dine in London or Manchester, and by the short sea route vi î Stranraer breakfast in Larne or Whitehead, and be right under these cliffs long before noon. Mr. Wise has kept well in mind the motto of the Belfast Field Club, of which he is a member, "Preservation, not Extinction," and the herring gulls which nest along the cliffs here in large numbers were disturbed as little as possible; some even nested on the partly made path. He has been careful to preserve the natural weathered surface of the rock all along the path ; it has only been broken where absolutely necessary for safety, and geologists are kindly requested to follow this example. They will find abundance of good material quarried out at many places quite close to the path, including good samples of the vesicular portions of the flows, with the orrginal vesicles now filled with various zeolites.

R. WELCH.

\section{A GREAT PERSIAN TRAVELLER.}

THE fascination which countries "old in story" exercise on many minds is more easily recognised than explained. But the existence of this fascination being once admitted, it is not difficult to understand why a peculiar glamour should attach to Persia, a land of which the history extends almost as far back as any authentic record of the human race, other than that derived from fossil bones or implements, can be said to exist. Nor is this the only attraction which Persia possesses, for although it is inhabited by the most civilised people of Asia, the greater portion of the Persian plateau was, until the last thirty years of the nineteenth century, almost unexplored by Europeans, and even at the commencement of the twentieth century no railway has crossed the Persian frontier, and the only road constructed for wheeled carriages, that from Resht to Teheran, is of

I "Ten Thousand Miles in Persia, or Eight Years in Irán." By Major Percy Molesworth Sykes (Queen's Bays), H. M. Consul, Kermán and Persian Baluchistan. Pp. $x v+48 r$; with numerous illustrations and map.
(London: John Murray.) no great length and is said to be in bad condition. In many respects the Persia of the present day resembles western Europe three hundred years ago, or perhaps in some respects even earlier. The general mode of travel is on horseback, the traveller's baggage and all merchandise are carried on pack animals, the roads are insecure and robbers abound. Even in the latter half of the nineteenth century, in eastern Persia and Baluchistan, raids by armed bands were of common occurrence, whilst less than thirty years ago Turcoman hordes from the north swept over northern Persia as far as the gates of Yezd and Isfahan, and murdered, plundered or dragged away as slaves the unfortunate inhabitants whom they encountered. Almost to this day the history of the tribal chieftains and of the provincial governors in eastern Persia and Baluchistan resembles that of European princes in the middle ages, when it was a rare exception for any man of note to live or die peaceably.

But a great change is gradually being effected in Persia, as in so many other countries. The Turcoman forays were summarily ended by Skobeleff's sweeping destruction of the raiding clans at Geok-tepe, a consummation aptly compared by Major Sykes to the more recent annihilation of the Soudanese slave-drivers at Omdurman. The "chapaos" of the Baluchis have been checked by the division of Baluchistan between Persian and British rule, and the frontiers between Afghanistan, Persia and British Baluchistan have been defined and mapped. The central government in Persia has gained power, and has been able during the last half century, despite many shortcomings, to do something for the protection of the people and the encouragement of agriculture and trade.

The author of "Ten Thousand Miles in Persia" has consequently had the advantage of studying the country at an interesting time. Few of the travellers in Persia since the time of Alexander the Great have had better opportunities or been better qualified than Major Sykes, who is an energetic explorer, a good linguist and a sympathetic student of Persian life and history. Several portions of his travels in eastern Persia and Baluchistan have already been briefly described in the Geographical Journal, but fuller accounts are given in the present work, together with numerous notes on the physical geography, history and people of the countries traversed. The various journeys of the author are not confined to eastern Persia. At one time or another he has traversed all the principal routes, including the well-known road from the Persian Gulf to the Caspian by Shiraz, Isfahan and Teheran; but, as he points out in his preface, he has touched but lightly on the provinces and cities of Persia that were fully dealt with in Lord Curzon's work, and has chiefly treated of those parts of the country, in eastern Persia and Baluchistan, that were previously less well known. A very large part of the book treats of journeys and researches of various kinds in the province of Kerman and in Persian Baluchistan, but in the execution of consular duties interesting visits were made to Sistan and Kain in one direction, and to the Persian Gulf, Basra (Bussorah) and Shuster in the other.

The additions made by Major Sykes to our knowledge of the geography of eastern Persia and Baluchistan are numerous, and they have in many cases greatly changed the map. For instance, by ascertaining that the stream flowing past Bampur does not reach the sea by the Rapsh, but is, like so many other Persian rivulets, evaporated in a "kavir," or salt marsh, he has added at least 20,000 square miles to the Persian inland drainage area, from which no water flows to the ocean. He has also aided materially in completing the investigation of the great desert region of Khorassan, called Dasht-iKavir or Dasht-i-Lut in maps. He shows that the name

NO. I7 I 3, VOL. 66] 